\title{
СОДЕРЖАНИЕ ТЯЖЕЛЫХ МЕТАЛЛОВ (ТМ) В ЛЕКАРСТВЕННЫХ РАСТЕНИЯХ ИНДУСТРИАЛЬНЫХ РАЙОНОВ КУРСКОЙ ОБЛАСТИ
}

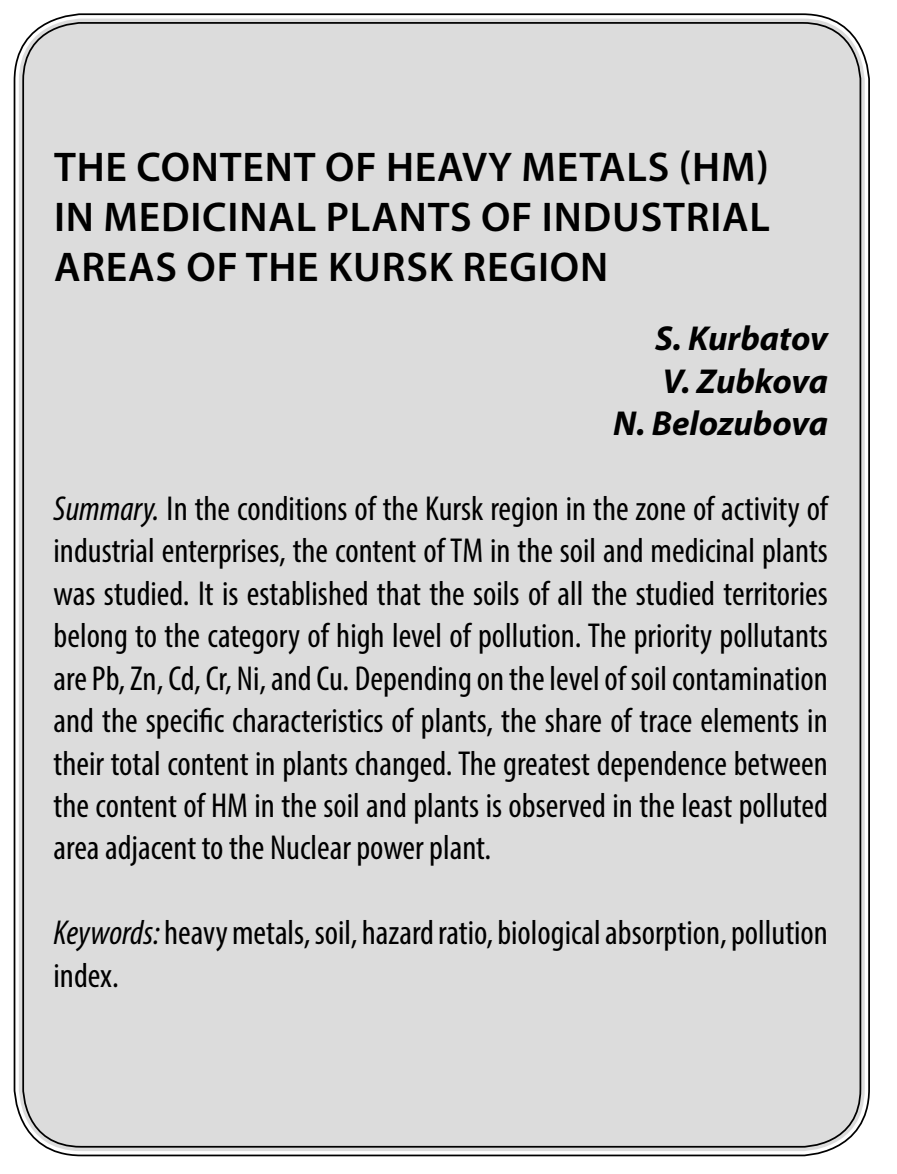

Л екарственное сырье, и готовые растительные продукты из него содержат сложные смеси органических соединений, таких как жирные кислоты, стерины, алкалоиды, флавоноиды, полифенолы, гликозиды, сапонины, дубильные вещества, терпены и т.д. Качество сырья и полученного из него продукта определяется в первую очередь эдафическими и сезонными условиями мест произрастания, а также антропогенной нагрузкой, в том числе загрязнением почвы тяжелыми металлами, которое является существенной проблемой, приводящей наряду с негативным влиянием на почвенные процессы к снижению продуктивных и экологических функций экосистем $[2,11 ; 19 ; 20]$.

Токсичность тяжелых металлов для почвенной микрофлоры зависит от $\mathrm{pH}$, наличия различных анионов и катионов, содержания глинистых минералов, гидроксидов металлов полуторных окислов, количества органического вещества, форм химических соединений, в которых встречаются ТМ [16; 21].

\author{
Курбатов Сергей Андреевич \\ Аспирант, Российский государственный социальный \\ университет (Москва) \\ s.kurbatoff@icloud.com \\ Зубкова Валентина Михайловна \\ Д.б.н., профессор, Российский государственный \\ сочиальный университет (Москва) \\ vmzubkova@yandex.ru \\ Белозубова Наталья Юрьевна \\ К.б.н., Российский государственный сочиальный \\ университет (Москва) \\ gerlinger_natali@mail.ru
}

Аннотация. В условиях Курской области в зоне деятельности промышленных предприятий исследовано содержание ТМ в почве и лекарственных растениях. Установлено, что почвы всех исследуемых территорий относятся к категории высокого уровня загрязнения. Приоритетными загрязнителями являются $\mathrm{Pb}, \mathrm{Zn}, \mathrm{Cd}, \mathrm{Cr}, \mathrm{Ni}$, Cu. В зависимости от уровня загрязнения почв и видовых особенностей растений изменялось долевое участие микроэлементов в общем их содержании в растениях. Наибольшая зависимость между содержанием ТМ в почве и растениях наблюдается на наименее загрязненном участке, прилегающем к АЭС.

Ключевые слова: тяжелые металлы, почва, коэффициент опасности, биологическое поглощение, индекс загрязнения.

Опасность повышения концентрации ТМ в почве возникает не только из-за их токсичности для населяющих её живых организмов, но и из-за способности ТМ накапливаться в почве в различных органических и неорганических коллоидах, сохраняясь в которых в течение длительного времени ТМ снова могут стать доступными для живых организмов, в том числе растений, при изменении почвенных условий.

Поглощение тяжелых металлов растениями и последующее накопление их в организме человека вследствие биомагнификации вызывают проблемы как с состоянием его здоровья, так и негативными изменениями состояния окружающей среды [7; 11].

Тяжелые металлы считаются одним из основных источников загрязнения почвы. Некоторые из них (Fe, $\mathrm{Zn}$, Са и Mg) имеют биологическое значение для живых организмов, в том числе для человека, поэтому существуют нормы потребления этих элементов или адекват- 
Таблица 1. Приоритетные загрязнители промышленных предприятий Курской области

\begin{tabular}{|c|c|c|}
\hline Предприятие & Координаты & Загрязнители \\
\hline $\begin{array}{l}\text { ООО «Курский аккумуляторный } \\
\text { завод» }\end{array}$ & $\begin{array}{l}\text { СШ } 51^{\circ} 40^{\prime} 5^{\prime \prime} \\
\text { ВД } 35^{\circ} 37^{\prime} 20^{\prime \prime}\end{array}$ & Соединения свинца, никеля и кадмия \\
\hline $\begin{array}{l}\text { Филиал АО «Концерн } \\
\text { Росэнергоатом» Курская атомная } \\
\text { станция» }\end{array}$ & $\begin{array}{l}\text { СШ } 51^{\circ} 40^{\prime} 5^{\prime \prime} \\
\text { ВД } 35^{\circ} 37^{\prime} 20^{\prime \prime}\end{array}$ & $\begin{array}{l}\text { Фенолы, цианиды, нефтепродукты, соединения кадмия, свинца, } \\
\text { меди, цинка, мышьяка; }\end{array}$ \\
\hline ООО Курскхимволокно» & $\begin{array}{l}\text { СШ } 51^{\circ} 39^{\prime} 22.932^{\prime \prime} \\
\text { ВД } 36^{\circ} 4^{\prime} 48.792^{\prime \prime}\end{array}$ & Соединения свинца, цинка, хрома, кадмия, нефтепродукты \\
\hline ОАО Курскрезинотехника» & $\begin{array}{l}\text { СШ } 51^{\circ} 40^{\prime} 34.824^{\prime \prime} \\
\text { ВД } 36^{\circ} 9^{\prime} 5.436^{\prime \prime}\end{array}$ & $\begin{array}{l}\text { Соединения } \mathrm{Zn}, \mathrm{Cd}, \mathrm{Pb}, \mathrm{Cr}, \mathrm{H}_{2} \mathrm{~S}, \mathrm{CS} 2, \mathrm{CO}, \mathrm{NH}_{3} \text {, кислоты, } \\
\text { органические вещества, растворители, летучие вещества, } \\
\text { сульфиды, пыль }\end{array}$ \\
\hline $\begin{array}{l}\text { АО «Михайловский ГОК } \\
\text { им. А.В. Варичева» }\end{array}$ & $\begin{array}{l}\text { СШ } 52^{\circ} 18^{\prime} 30.744^{\prime \prime} \\
\text { ВД } 35^{\circ} 23^{\prime} 22.848^{\prime \prime}\end{array}$ & $\begin{array}{l}\text { Железо, никель, хром, медь, марганец, ртуть, талий, молибден, } \\
\text { алюминий. }\end{array}$ \\
\hline
\end{tabular}

ный уровень потребления, а также рекомендованные лечебные и диетические дозы. Другие ТМ и металлоиды (As, $\mathrm{Cd}, \mathrm{Pb}$ и метилированные формы $\mathrm{Hg}$ ) не имеют известной биологической значимости в биохимии и физиологии человека, и потребление их даже в очень низких концентрациях может быть токсичным [16;21].

Данная проблема становится особенно актуальной на территориях с разноплановым и многокомпонентным техногенным воздействием.

Целью наших исследований явилось изучение содержания тяжёлых металлов в дикорастущих видах травянистых лекарственных растений в зависимости от экологического состояния почв, находящихся в зоне деятельности промышленных предприятий Курской области.

\section{Мето ы}

Исследования проведены в условиях 2020 г. в Курской области - регионе с одной из техногенно трансформированных территорий РФ, на которой сосредоточено большое количество разнопрофильных промышленных предприятий. Одними из крупнейших среди них являются Филиал АО «Концерн Росэнергоатом» «Курская атомная станция» (исследуемая территория 1), ООО «Курский аккумуляторный завод» (исследуемая территория 2), ООО «Курскхимволокно» - (исследуемая территория 3), ОАО «Курскрезинотехника» (исследуемая территория 4), АО «Михайловский ГОК им. А.В. Варичева» (исследуемая территория 5), специализирующиеся на производстве электроэнергии, свинцово-кислотных и герметичных никель-кадмиевых аккумуляторов, полиамидных нитей и волокон, производстве резинотехнических изделий и добыче железной руды, соответственно.

Основные загрязняющие вещества, образующиеся в производственных циклах выше указанных предприятий приведены в таблице 1.
В ходе исследования определено содержание тяжёлых металлов в почве и травянистых многолетних растениях - подорожнике большом (Plantago major); крапиве двудомной (Urtica dioica); тысячелистнике обыкновенном (Achillea millefollium). На каждой из изучаемых территорий в трехкратной повторности отбирали по десять растений исследуемых видов. Минерализацию воздушно-сухой массы растительных образцов проводили методом сухого озоления

Отбор проб почвы для всех анализов осуществлен в соответствии с требованиями к отбору при общих и локальных загрязнениях, изложенными в ГОСТ 17.4.3.012017, ГОСТ 17.4.4.02-2017, ГОСТ Р 58595-2019, а также методических указаниях, по определению ТМ в почвах сельхозугодий и продукции растениеводства $[4 ; 5 ; 6 ; 10]$.

Определение тяжелых металлов в почве и растениях проводили в испытательной лаборатории ООО «Центр сертификации и экологического мониторинга агрохимической службы «Московский» методом атомно-абсорбционной спектрометрии.

Для построения рядов накопления тяжелых элементов в техногеохимических аномалиях использовали коэффициенты концентрации элементов Кк в поверхностном горизонте относительно фона: Ккі $=\mathrm{Ci} / \mathrm{Ci \phi}$, где Сi и Сіф-фактическое и фоновое содержание і-ого элемента в почве. Суммарный показатель загрязнения рассчитывали по формуле CПЗ (Zc) $=\Sigma \mathrm{Kc}-(\mathrm{n}-1)$ [3].

Разницу в биофильности тяжелых металлов устанавливали по показателю коэффициента биологического поглощения (КБП), определяемого как отношение содержания элемента в золе растений к содержанию в почве [13].

Коэффициенты опасности Ко в растениях определяли как отношение Ко = Сі / ПДКі, где Сі и ПДКі - факти- 
Таблица 2. Содержание тяжелых металлов в почвах исследуемых биотопов, мг/кг

\begin{tabular}{|c|c|c|c|c|c|c|c|}
\hline $\begin{array}{l}\text { Участок/ } \\
\text { Элемент }\end{array}$ & Zn & $\mathrm{Pb}$ & $\mathrm{Cr}$ & $\mathrm{Cd}$ & $\mathrm{Ni}$ & $\mathrm{Cu}$ & Zc \\
\hline 1. & $\begin{array}{l}61,2 \pm 5,8 \\
1,17\end{array}$ & $\begin{array}{l}62,4 \pm 6,1 \\
3,90\end{array}$ & $\begin{array}{l}34,6 \pm 2,1 \\
0,42\end{array}$ & $\begin{array}{l}0,95 \pm 0,01 \\
31,80\end{array}$ & $\begin{array}{l}11,4 \pm 2,4 \\
0,35\end{array}$ & $\begin{array}{l}83,4 \pm 4,1 \\
3,79\end{array}$ & 37 \\
\hline 2. & $\begin{array}{l}121,7 \pm 10,0 \\
2,34\end{array}$ & $\begin{array}{l}151,5 \pm 2,8 \\
9,48\end{array}$ & $\begin{array}{l}71,0 \pm 2,1 \\
0,86\end{array}$ & $\begin{array}{l}1,60 \pm 0,08 \\
53,30\end{array}$ & $\begin{array}{l}47,6 \pm 1,9 \\
1,44\end{array}$ & $\begin{array}{l}87,0 \pm 6,3 \\
3,95\end{array}$ & 66 \\
\hline 3. & $\begin{array}{l}136,2 \pm 6,1 \\
2,61\end{array}$ & $\begin{array}{l}73,6 \pm 3,4 \\
4,60\end{array}$ & $\begin{array}{l}49,26 \pm 4,0 \\
0,60\end{array}$ & $\begin{array}{l}1,10 \pm 0,02 \\
3,66\end{array}$ & $\begin{array}{l}21,0 \pm 6,1 \\
0,63\end{array}$ & $\begin{array}{l}76,3 \pm 5,2 \\
3,46\end{array}$ & 45 \\
\hline 4. & $\begin{array}{l}153 \pm 7,1 \\
2,94\end{array}$ & $\begin{array}{l}147,6 \pm 3,9 \\
9,22\end{array}$ & $\begin{array}{l}67,8 \pm 5,1 \\
0,82\end{array}$ & $\begin{array}{l}0,96 \pm 0,04 \\
3,20\end{array}$ & $\begin{array}{l}34,4 \pm 6,3 \\
1,04\end{array}$ & $\begin{array}{l}84,6 \pm 6,3 \\
3,84\end{array}$ & 45 \\
\hline 5. & $\begin{array}{l}134,9 \pm 6,9 \\
2,59\end{array}$ & $\begin{array}{l}38,8 \pm 2,2 \\
2,42\end{array}$ & $\begin{array}{l}79,6 \pm 1,9 \\
0,97\end{array}$ & $\begin{array}{l}1,69 \pm 0,01 \\
5,63\end{array}$ & $\begin{array}{l}112,8 \pm 7,1 \\
3,41\end{array}$ & $\begin{array}{l}93,4 \pm 2,9 \\
4,24\end{array}$ & 65 \\
\hline ПДК & 60 & 30 & 50 & 1 & 100 & 85 & \\
\hline$\Phi \mathrm{OH}^{* *}$ & 52 & 16 & 82 & 0,3 & 33 & 22 & \\
\hline Класс опасности & 1 & 1 & 2 & 1 & 2 & 2 & \\
\hline
\end{tabular}

Примечание: * - за фоновое содержание элементов принято их количество, установленное в почве Курского чернозема стандартного образца (свидетельство СП-1 № 901-90) в пределах всей области [15].

Таблица 3. Средние концентрации тяжелых металлов в лекарственных растениях, мг/кг

\begin{tabular}{|c|c|c|c|c|c|c|}
\hline Участок/элемент & Zn & $\mathrm{Pb}$ & $\mathrm{Cr}$ & Cd & $\mathrm{Ni}$ & $\mathrm{Cu}$ \\
\hline \multicolumn{7}{|l|}{ Plantago major } \\
\hline 1. & $31,7 \pm 3,2$ & $7,1 \pm 1,1$ & $19,5 \pm 3,1$ & $1,29 \pm 0,4$ & $24,3 \pm 1,2$ & $18,9 \pm 2,7$ \\
\hline 2. & $51,1 \pm 5,4$ & $12,9 \pm 1,4$ & $26,1 \pm 3,7$ & $2,15 \pm 0,1$ & $35,9 \pm 2,4$ & $49,4 \pm 4,9$ \\
\hline 3. & $34,0 \pm 2,3$ & $8,4 \pm 2,7$ & $25,7 \pm 1,3$ & $1,65 \pm 0,3$ & $27,2 \pm 2,2$ & $31,4 \pm 3,4$ \\
\hline 4. & $43,9 \pm 6,1$ & $10,0 \pm 1,0$ & $22,0 \pm 2,5$ & $1,60 \pm 0,1$ & $31,2 \pm 3,0$ & $43,8 \pm 4,1$ \\
\hline 5 & $43,5 \pm 4,6$ & $10,6 \pm 2,0$ & $29,6 \pm 2,4$ & $1,95 \pm 0,2$ & $31,0 \pm 1,7$ & $29,0 \pm 4,1$ \\
\hline \multicolumn{7}{|l|}{ Urtica dioica } \\
\hline 1. & $18,3 \pm 1,6$ & $5,4 \pm 0,8$ & $15,7 \pm 1,4$ & $0,96 \pm 0,1$ & $16,7 \pm 1,5$ & $11,8 \pm 1,1$ \\
\hline 2. & $41,2 \pm 4,8$ & $8,3 \pm 1,0$ & $22,7 \pm 4,8$ & $1,56 \pm 0,6$ & $30,3 \pm 1,3$ & $34 \pm 2,4$ \\
\hline 3. & $27,7 \pm 3,4$ & $6,3 \pm 1,2$ & $21,1 \pm 3,5$ & $1,00 \pm 0,1$ & $24,8 \pm 2,1$ & $18,7 \pm 1,2$ \\
\hline 4. & $29,4 \pm 1,3$ & $6,4 \pm 1,2$ & $19,7 \pm 2,7$ & $1,10 \pm 0,4$ & $28,3 \pm 2,8$ & $31,4 \pm 3,4$ \\
\hline 5. & $30,4 \pm 2,3$ & $6,9 \pm 1,0$ & $22,9 \pm 2,6$ & $1,27 \pm 0,3$ & $28,1 \pm 2,3$ & $16,7 \pm 1,8$ \\
\hline \multicolumn{7}{|c|}{ Achillea millefollium } \\
\hline 1. & $26,4 \pm 2,6$ & $9,7 \pm 1,9$ & $21,2 \pm 1,9$ & $0,68 \pm 0,1$ & $27,4 \pm 4,2$ & $29,5 \pm 1,6$ \\
\hline 2. & $44,1 \pm 5,1$ & $16,2 \pm 2,7$ & $29,6 \pm 1,7$ & $1,40 \pm 0,4$ & $54,9 \pm 5,4$ & $43,5 \pm 4,3$ \\
\hline 3. & $39,3 \pm 3,7$ & $11,8 \pm 1,4$ & $29,7 \pm 2,0$ & $1,34 \pm 0,2$ & $37,4 \pm 3,1$ & $30,1 \pm 2,9$ \\
\hline 4. & $38,1 \pm 4,1$ & $15,1 \pm 1,4$ & $24,6 \pm 2,7$ & $1,60 \pm 0,2$ & $51,1 \pm 4,6$ & $39,4 \pm 3,1$ \\
\hline 5. & $47,6 \pm 4,9$ & $18,9 \pm 2,5$ & $33,7 \pm 3,7$ & $2,12 \pm 0,6$ & $71,6 \pm 7,6$ & $31,0 \pm 2,4$ \\
\hline
\end{tabular}

ческая концентрация і-ого элемента в растениях и предельно допустимая [17].

Наличие зависимости между содержанием тяжёлых металлов в почве и растениях устанавливали с помощью корреляционного анализа (табл. 8).

\section{Результаты и обсухмение}

Установлено, что ТМ оказывают значительный токсический эффект на живые организмы. Токсичность определяют физические и химические особенности элементов: электронная конфигурация, электроотрица- 
Таблица 4. Коэффициенты опасности растительного сырья (содержание элемента в растениях/ПДК)

\begin{tabular}{|c|c|c|c|c|c|c|}
\hline Участок & Zn & $\mathrm{Pb}$ & $\mathrm{Cr}$ & Cd & $\mathrm{Ni}$ & $\mathrm{Cu}$ \\
\hline \multicolumn{7}{|c|}{ Plantago major } \\
\hline 1 & 2,10 & 1,18 & 19,50 & 1,29 & 24,30 & 3,78 \\
\hline 2 & 3,40 & 2,15 & 26,10 & 2,15 & 35,90 & 9,88 \\
\hline 3 & 2,26 & 1,40 & 25,70 & 1,65 & 27,2 & 6,28 \\
\hline 4 & 2,92 & 1,60 & 22,00 & 1,60 & 31,2 & 8,76 \\
\hline 5 & 2,90 & 1,76 & 29,60 & 1,95 & 31,00 & 5,80 \\
\hline \multicolumn{7}{|c|}{ Urtica dioica } \\
\hline 1 & 1,22 & 0,90 & 15,70 & 0,96 & 16,70 & 2,36 \\
\hline 2 & 2,74 & 1,38 & 22,70 & 1,56 & 30,30 & 6,80 \\
\hline 3 & 1,84 & 1,05 & 21,10 & 1,00 & 24,80 & 3,74 \\
\hline 4 & 1,96 & 1,06 & 19,70 & 1,1 & 28,30 & 6,28 \\
\hline 5 & 2,02 & 1,15 & 22,90 & 1,27 & 28,10 & 3,34 \\
\hline \multicolumn{7}{|c|}{ Achillea millefollium } \\
\hline 1 & 1,76 & 1,61 & 21,20 & 0,68 & 27,40 & 5,90 \\
\hline 2 & 2,74 & 2,70 & 29,60 & 1,40 & 54,90 & 8,70 \\
\hline 3 & 2,26 & 1,96 & 29,70 & 1,34 & 37,40 & 6,02 \\
\hline 4 & 2,54 & 2,51 & 24,60 & 1,60 & 51,10 & 7,88 \\
\hline 5 & 3,10 & 3,15 & 33,70 & 2,12 & 71,60 & 6,20 \\
\hline
\end{tabular}

тельность, ионизация, величина окислительно-восстановительного потенциала, сродство к отдельным функциональным группам, а также способность проникать через клеточную оболочку и образовывать прочные соединения на поверхности и внутри клетки. Приоритетными загрязнителями окружающей среды Курской области являются $\mathrm{Pb}, \mathrm{Zn}, \mathrm{Cd}, \mathrm{Cr}, \mathrm{Ni}, \mathrm{Cu}$. Соединения этих элементов высоко токсичны, широко распространены в окружающей среде и способны к накоплению в пищевых цепях $[1 ; 8 ; 18]$.

Результаты наших исследований показали, что концентрация кадмия в отдельных биотопах превышало фоновое значение в 53,3; никеля - 3,41; свинца - 9,48; меди - 4,24; цинка - 2,94; хрома - 0,97 раза. Оценка экологического состояния почв по суммарному коэффициенту загрязнения, рассчитанного по шести изучаемым элементам, позволяет отнести районы исследования к категории с высоким уровнем загрязнения. По суммарному индексу загрязнения исследуемые участки располагаются в следующей последовательности: участок $1<$ участок $3<$ участок < участок $5<$ участок 2 (табл. 2).

Почвы исследуемых районов имеют высокие концентрации ТМ по сравнению с фоновым содержанием и ПДК. Значительные по площади территории этой зоны относятся к категории опасные.

Средняя концентрация тяжелых металлов в изучаемых лекарственных растениях представлены в таблице 3.
Видовые особенности растений сыграли существенную роль в общем накоплении ТМ.

Так анализ содержания в растениях элементов, относящихся к первой группе токсичности показал, что наименьшим концентрированием $\mathrm{Zn}$ и $\mathrm{Pb}$ отличается крапива, Cd - Achillea millefollium, а наибольшим - по Zn и $\mathrm{Cd}$ - Plantago major, nо Pb - Achillea millefollium.

По суммарному накоплению тяжелых металлов в Plantago major по сравнению с минимальными их содержаниями в растениях исследуемые функциональные площадки можно расположить в следующий ряд:

участок $2(16,45)>$ участок $4(13,56)>$ участок $5(13,37)>$ участок $3(11,73)>$ участок $1(9,31)$.

Аналогично распределяются участки по накоплению тяжелых металлов подорожником:

участок $2(12,31)>$ участок $4(9,99)>$ участок $5(9,33)>$ участок $3(8,54)>$ участок $1(6,47)$.

В отличие от выше указанных растений в Achillea millefollium распределение по суммарному накоплению тяжелых металлов по исследуемым территориям происходит следующим образом:

участок $5(18,24)>$ участок $2(16,39)>$ участок $4(15,31)>$ участок $3(12,96)>$ участок $5(18,24)$.

Оценку содержания $\mathrm{Pb}$ и $\mathrm{Cd}$ проводили по ПДК в соответствии с Государственной Фармакопиеей, для остальных элементов - в соответствии с ПДК для лекарственных растений и разнотравья [9; 12; 14]. 
Таблица 5. Долевое участие тяжелых металлов в общем их содержании в растениях

\begin{tabular}{|c|c|c|c|c|c|c|}
\hline Участок/элемент & Zn & $\mathrm{Pb}$ & $\mathrm{Cr}$ & Cd & $\mathbf{N i}$ & $\mathrm{Cu}$ \\
\hline \multicolumn{7}{|l|}{ Plantago major } \\
\hline 1 & 30,84 & 6,90 & 18,98 & 1,25 & 23,65 & 18,38 \\
\hline 2 & 28,79 & 7,26 & 14,70 & 1,22 & 20,21 & 27,82 \\
\hline 3 & 26,49 & 6,54 & 20,03 & 1,28 & 21,19 & 24,47 \\
\hline 4 & 28,76 & 6,57 & 14,46 & 1,05 & 20,47 & 28,69 \\
\hline 5 & 29,86 & 7,27 & 20,33 & 1,33 & 21,29 & 19,92 \\
\hline \multicolumn{7}{|l|}{ Urtica dioica } \\
\hline 1 & 26,57 & 7,84 & 22,79 & 1,40 & 24,26 & 17,14 \\
\hline 2 & 29,84 & 6,02 & 16,45 & 1,12 & 21,94 & 24,63 \\
\hline 3 & 27,81 & 6,32 & 21,18 & 1,02 & 24,89 & 18,78 \\
\hline 4 & 25,27 & 5,50 & 16,93 & 0,94 & 24,34 & 27,02 \\
\hline 5 & 28,61 & 6,49 & 21,54 & 1,19 & 26,45 & 15,72 \\
\hline \multicolumn{7}{|c|}{ Achillea millefollium } \\
\hline 1 & 22,98 & 8,44 & 18,45 & 0,59 & 23,85 & 25,69 \\
\hline 2 & 23,24 & 8,53 & 15,61 & 0,73 & 28,95 & 22,94 \\
\hline 3 & 26,26 & 7,89 & 19,85 & 0,89 & 24,99 & 20,12 \\
\hline 4 & 22,42 & 8,88 & \begin{tabular}{|l|}
14,47 \\
\end{tabular} & 0,95 & 30,08 & 23,20 \\
\hline 5 & 23,22 & 9,23 & 16,44 & 1,02 & 34,97 & 15,12 \\
\hline
\end{tabular}

Таблица 6. Коэффициенты биологического поглощения

\begin{tabular}{|c|c|c|c|c|c|c|}
\hline $\begin{array}{l}\text { Участок/ } \\
\text { элемент }\end{array}$ & Zn & $\mathrm{Pb}$ & $\mathrm{Cr}$ & Cd & $\mathrm{Ni}$ & $\mathrm{Cu}$ \\
\hline \multicolumn{7}{|c|}{ Plantago major } \\
\hline 1 & 0,51 & 0,11 & 0,56 & 1,35 & 2,13 & 0,22 \\
\hline 2 & 0,41 & 0,08 & 0,36 & 1,34 & 0,75 & 0,56 \\
\hline 3 & 0,24 & 0,11 & 0,52 & 1,5 & 1,29 & 0,41 \\
\hline 4 & 0,28 & 0,06 & 0,32 & 1,66 & 0,90 & 0,51 \\
\hline 5 & 0,32 & 0,27 & 0,37 & 1,15 & 0,27 & 0,31 \\
\hline \multicolumn{7}{|c|}{ Urtica dioica } \\
\hline 1 & 0,29 & 0,08 & 0,45 & 1,00 & 1,46 & 0,14 \\
\hline 2 & 0,33 & 0,05 & 0,31 & 0,97 & 0,63 & 0,39 \\
\hline 3 & 0,20 & 0,08 & 0,42 & 0,90 & 1,18 & 0,24 \\
\hline 4 & 0,19 & 0,04 & 0,29 & 1,14 & 0,82 & 0,37 \\
\hline 5 & 0,22 & 0,17 & 0,28 & 0,75 & 0,24 & 0,17 \\
\hline \multicolumn{7}{|c|}{ Achillea millefollium } \\
\hline 1 & 0,43 & 0,15 & 0,61 & 0,71 & 2,40 & 0,35 \\
\hline 2 & 0,36 & 0,10 & 0,41 & 0,87 & 1,15 & 0,50 \\
\hline 3 & 0,28 & 0,16 & 0,60 & 1,21 & 1,78 & 0,39 \\
\hline 4 & 0,24 & 0,10 & 0,36 & 1,66 & 1,48 & 0,46 \\
\hline 5 & 0,35 & 0,48 & 0,42 & 1,25 & 0,63 & 0,33 \\
\hline
\end{tabular}


Таблица 7. Корреляционная зависимость суммарных концентраций содержания ТМ в почвах (мг/кг) и концентраций содержания ТМ в лекарственных растениях.

\begin{tabular}{|c|c|c|c|}
\hline $\begin{array}{l}\text { Суммарное } \\
\text { загрязнение участка } \\
\text { (СПз/участок) }\end{array}$ & Plantago major & Urtica dioica & Achillea millefollium \\
\hline $37(1)$ & $\begin{array}{l}\text { 0,98 } \\
\text { Сильная прямая }\end{array}$ & $\begin{array}{l}\text { 0,95 } \\
\text { Сильная прямая }\end{array}$ & $\begin{array}{l}\text { 0,98 } \\
\text { Сильная прямая }\end{array}$ \\
\hline $45(3)$ & \begin{tabular}{|l}
0,34 \\
Умеренная прямая
\end{tabular} & $\begin{array}{l}\text { 0,30 } \\
\text { Слабая прямая }\end{array}$ & \begin{tabular}{|l} 
0,34 \\
Умеренная прямая
\end{tabular} \\
\hline $45(4)$ & $\begin{array}{l}\text { 0,58 } \\
\text { Значительная прямая }\end{array}$ & $\begin{array}{l}\text { 0,50 } \\
\text { Значительная прямая }\end{array}$ & $\begin{array}{l}\text { 0,58 } \\
\text { Значительная прямая }\end{array}$ \\
\hline $65(5)$ & $\begin{array}{l}\text { 0,38 } \\
\text { Умеренная прямая }\end{array}$ & $\begin{array}{l}\text { 0,24 } \\
\text { Слабая прямая }\end{array}$ & $\begin{array}{l}\text { 0,38 } \\
\text { Умеренная прямая }\end{array}$ \\
\hline $66(2)$ & \begin{tabular}{|l}
0,31 \\
Умеренная прямая \\
\end{tabular} & $\begin{array}{l}\text { 0,23 } \\
\text { Слабая прямая }\end{array}$ & $\begin{array}{l}\text { 0,31 } \\
\text { Умеренная прямая }\end{array}$ \\
\hline
\end{tabular}

Во всех исследуемых образцах растительного сырья содержание $\mathrm{Zn}, \mathrm{Pb}, \mathrm{Cr}$, Ni, Cu превышало пределы нормальных концентраций (табл. 4).

Содержание Cd в Urtica dioica, Achillea millefollium, отобранных на первом участке, не превышали ПДК, варьировали в пределах 0,68-0,96 мг/кг и были ниже концентраций Cd в растениях, собранных на участках 2-5 в 1,12-1,56 раза.

Взаимодействия между элементами, наблюдаемые в растениях показывают, насколько сложны эти процессы, так как, они могут быть то антагонистическими, то синергетическими, об этом говорят изменения долевого участия микроэлементов в общем их содержании в различных растениях в зависимости от уровня загрязнения почв.

Приведенные результаты показывают, что долевое участие элементов в общем их содержании определялось как видом растения, так и уровнем загрязнения почвы (табл. 5).

Так, на наименее загрязненном участке долевое участие элементов изменялось в следующей последовательности:

Plantago major $-\mathrm{Zn}>\mathrm{Cu}>\mathrm{Ni}>\mathrm{Cr}>\mathrm{Pb}>\mathrm{Cd}$

Urtica dioica - $\mathrm{Zn}>\mathrm{Ni}>\mathrm{Cr}>\mathrm{Cu}>\mathrm{Pb}>\mathrm{Cd}$

Achillea millefollium - $\mathrm{Cu}>\mathrm{Ni}>\mathrm{Zn}>\mathrm{Cr}>\mathrm{Pb}>\mathrm{Cd}$

При наибольшем уровне загрязнения почвы ряды распределения ТМ выглядели следующим образом:

Plantago major $-\mathrm{Zn}>\mathrm{Cu}>\mathrm{Ni}>\mathrm{Cr}>\mathrm{Pb}>\mathrm{Cd}$

Urtica dioica - $\mathrm{Zn}>\mathrm{Cu}>\mathrm{Ni}>\mathrm{Cr}>\mathrm{Pb}>\mathrm{Cd}$

Achillea millefollium - $\mathrm{Ni}>\mathrm{Zn}>\mathrm{Cu}>\mathrm{Cr}>\mathrm{Pb}>\mathrm{Cd}$.

То есть в крапиве возрастала доля меди, а в тысячелистнике - доля никеля и цинка. Это происходило в условиях, когда общий уровень загрязнения почвы уве- личивался в 1,81; никеля и цинка - в 4,11и - в 2 раза соответственно, уровень загрязнения медью практически не изменялся.

Для оценки эффективности поглощения элементов рассчитаны коэффициенты биологического поглощения (отношение содержание элемента в золе к его содержанию в почве) (табл. 6).

Наибольшее значение КБП цинка установлены в пробax Plantago major на участке 1; Pb в пробах Urtica dioica на участке 1, Cr и Ni в пробах Achillea millefollium на участке 1; Cd в пробах Plantago major и Achillea millefollium на участке 4.

При повышении концентрации тяжелых металлов в почве в целом отмечено повышение концентрационной способности исследуемых растений по отношению к ним, однако наибольшая зависимость между содержания ТМ в почве и растениях наблюдается на наименее загрязненном участке (табл. 7).

\section{Эак^ючение}

Оценка экологического состояния почв территорий, прилегающих к промышленным предприятиям Курской области, позволяет отнести исследованные почвы к категории с высоким уровнем загрязнения.

Повышенное загрязнение окружающей среды тяжелыми металлами вызывает загрязнение лекарственных растений, что может сказаться на их фармацевтической и медицинской ценности.

В связи с этим, использование лекарственных растений, выращенных на загрязненных тяжелыми металлами почвах, может быть одним из потенциальных путей проникновения последних в организм человека и животных. 


\section{ЛИТЕРАТУРА}

1. Абдуллаев С.Ф., Сафаралиев Н.М., Партоев К. Исследование биологического поглощения тяжелых металлов растением-фиторемедиантом-топинамбуром (Helianthus Tuberosus I.) //Химическая безопасность.-2019.— Т. 3.— № . 1.—C. 110-117.

2. Водяницкий Ю.Н. Оценка суммарной токсикологической загрязненности почв тяжелыми металлами и металлоидами //Агрохимия.— 2017.— № . 2. C. 56-63.

3. Водяницкий Ю.Н. Тяжелые и сверхтяжелые металлы и металлоиды в загрязненных почвах. - М.: ГНУ Почвенный институт им. В.В. Докучаева Россельхозакадемии. - 2009.- 92 .

4. ГОСТ 17.4.3.01-2017. Охрана природы. Почвы. Общие требования к отбору проб. М.: Стандартинформ. - 2018. — 3c.

5. ГОСТ 17.4.4.02-2017. Охрана природы. Почвы. Методы отбора и подготовки проб для химического, бактериологического, гельминтологического анализа. М.: Стандартинформ.-2018.- $10 \mathrm{c}$.

6. ГОСТ Р 58595-2019. Почвы. Отбор проб. М.: Стандартинформ.-2018. - 6 с.

7. Гулиева С.В.К., Керимова Р.Д.К., Юсифова М.Ю.К. Влияние тяжелых металлов на биохимические процессы в организме человека //Academy.- 2018.№. $12(39)$.

8. Зубкова В.М., Белозубова Н.Ю., Горбунова В.А. Влияние уровней загрязнения почвы цинком и свинцом на продуктивность и динамику накопления сухой массы растениями картофеля //ББК 40.2 А 24. - 2018.—C. 157.

9. К Каманина И.З., Каплина С.П., Салихова Ф.С. Содержание тяжелых металлов в лекарственных растениях // Научное обозрение. Биологические науки.2019.—№ 1.—C. 29-34; URL: https://science-biology.ru/ru/article/view?id=1130 (дата обращения: 25.03.2021).

10. Методические указания по определению ТМ в почвах сельхозугодий и продукции растениеводства.— М.: ЦИНА0, 1992. — 40 c.

11. Осипова В.П., Берберова Н.Т. Снижение токсичности соединений тяжелых металлов и нефтепродуктов применением антиоксидантов фенольного типа //«Новые функциональные материалы и высокие технологии» V Международная научная конференция, Тиват, Черногория, 25-29 сентября 2017 г.: тезисы докладов. — Иваново: Институт химии растворов им. ГА Крестова РАН, 2017.-142 c. ISBN978-5-905364-12-9 Редактор: Парфенюк ВИ.—2017.— C. 102.

12. ОФС.1.5.3.0009.15. Определение содержания тяжелых металлов и мышьяка в лекарственном растительном сырье и лекарственных растительных препаратах [Электронный ресурс]. URL: http://pharmacopoeia.ru/ofs-1-5-3-0009-15-opredelenie-soderzhaniya-tyazhelyh-metallov-i-myshyaka-v-lekarstvennomrastitelnom-syre-i-lekarstvennyh-rastitelnyh-preparatah/ (дата обращения: 24.11.2018).

13. Перельман А.И. Геохимия ландшафта.— М.: Высшая школа. - 1975.— 340 c.

14. Позняк С.С. Содержание некоторых тяжелых металлов в растительности полевых и луговых агрофитоценозах в условиях техногенного загрязнения почвенного покрова //Вестник Томского государственного университета. Биология. — 2011. — № . 1 (13).

15. Свидетельство на стандартный образец (СО) СП-1 (курский чернозем) № 901-90 (00К0152) по государственному реестру мер и измерительных приборов СССР (раздел стандартные образцы). 1990.

16. Ткаченко М.Н., Постовалов А.А. Определение биологической активности почвы при внесении тяжелых металлов //Ресурсосберегающие экологически безопасные технологии хранения и переработки сельскохозяйственной продукции. - 2018. - C. 492-499.

17. Толкач О.В. Поллютанто-депонирующая роль леса //Бореальные леса: состояние, динамика, экосистемные услуги. — 2017.— С. 299.

18. Fahimirad S., Hatami M. Heavy metal-mediated changes in growth and phytochemicals of edible and medicinal plants //Medicinal Plants and Environmental Challenges. - Springer, Cham, 2017.-C. 189-214.

19. Ghazaryan K. et al. Copper phytoremediation potential of wild plant species growing in the mine polluted areas of Armenia //Environmental Pollution. - 2019. T. 249.- C. 491-501.

20. Guo J., Kang Y., Feng Y. Bioassessment of heavy metal toxicity and enhancement of heavy metal removal by sulfate-reducing bacteria in the presence of zero valent iron //Journal of environmental management. - 2017. - T. 203.— C. 278-285.

21. Sandoval-Herazo L. C. et al. Effects of the use of ornamental plants and different substrates in the removal of wastewater pollutants through microcosms of constructed wetlands //Sustainability. — 2018. - T. 10.— №.5.—C. 1594.

( Курбатов Сергей Андреевич ( s.kurbatoff@icloud.com ), зубкова Валентина Михайловна ( vmzubkova@yandex.ru ), Белозубова Наталья Юрьевна ( gerlinger_natali@mail.ru ).

Журнал «Современная наука: актуальные проблемы теории и практики» 